An Introduction to International Co-operation. Africans wishing to come to the Institute should be in possession of bursaries either from their own country or from national or international foundations. Further information may be obtained from The Director, Geneva-Africa Institute, 2-4 route de Drize, Geneva, Switzerland.

\title{
Unesco Conference on the Development of Education in Africa
}

A CONFERENCE on the development of education in Africa was held at Addis Ababa from Is to 25 May and was attended by representatives from thirty-nine participating States and territories. The conference was inaugurated by His Imperial Majesty the Emperor of Ethiopia, Mr. Vittorino Veronese, the Director-General of Unesco, and Mr. Stein Rossen, the officer in charge of the Economic Commission for Africa (ECA). The Minister of Education of Ghana, Mr. A. Duwoona Hammond, was elected president of the conference.

The educational needs of the African States in relation to the economic and social development of the region were defined as follows: (a) finance for school construction, for non-African teachers and for providing scholarships for Africans to study abroad; $(b)$ equipment and books for secondary, general, technical, and agricultural schools; $(c)$ teachertraining institutions to produce primary teachers, and expatriate teachers for these and for expanded second-level programmes; (d) revision of the scope of education and of the content of textbooks in terms of the changing structure of existing economies and of the social and cultural conditions of Africa; $(e)$ education of girls; $(f)$ higher education to meet the urgent need for high-level manpower; $(g)$ adult education to eradicate illiteracy (it is estimated that there are about roo million illiterates); $(h)$ planning of educational expansion both in quantity and quality.

Among its recommendations the conference urged that the content of education should be related to the economic needs and cultures of Africa, greater weight being given to science and its application, and that in Africa, at its present stage of development, the highest priority in education should be accorded to ensuring that an adequate proportion of the population acquires at secondary and post-secondary levels the kinds of skills needed for economic development. The conference also recommended that programmes of study and research should be undertaken by Unesco, ECA, and Member States, as appropriate, on the following relationships between different patterns of development and manpower: timing and balance between educational and economic development, priorities within a balanced educational system; economic and social returns to be derived from investment in education; the problems faced by education in transition from a subsistence to a monetary economy; the technology of teaching, and the need to establish institutes in Africa for development and research in education.

\section{National Pedagogical Institute in Leopoldville}

A national Pedagogical Institute for the training of teachers in secondary and higher education has recently been opened in Leopoldville. The building and grounds of the Institute, at Gélo Binza on the outskirts of the town, have been provided by the Congolese Government, and Unesco has supplied staff and equipment.

The Institute offers a two-year course for training teachers for the first two or three years of secondary education. It will also provide a shorter, accelerated course for selected primary school teachers who would qualify to teach in the first and possibly second grades of secondary schools. Training courses for primary school inspectors, seminars and workshops for educational administrators and specialists, will also be organized. The Institute 
will provide assistance to any teacher-training school requesting it, and will work in close co-operation with representatives of Catholic and Protestant educational authorities in the Congo and with the University of Lovanium.

\section{Afro-Asian Studies in the University of Cambridge}

THE University of Cambridge has established a group for Afro-Asian Social Studies with a documentation centre and a seminar room. The centre contains recent reports on economic, political, and social questions and a bibliography arranged under regions and subjects. Research programmes and inter-disciplinary seminars are being organized. In October I $96 \mathrm{I}$ a post-graduate seminar was started on 'Elite Formation in Emergent States' held by Dr. E. Shils and Dr. A. I. Richards. From January 1962 there will be seminars on 'The Productivity of Peasant Agriculture', held by Professor Sir Joseph Hutchinson and Mr. Leonard Joy, and 'Economic Enclaves in Under-Developed Countries', held by Professor E. A. G. Robinson and Miss Phyllis Deane. The Inter-Disciplinary Seminar on African Problems, which has been held in Cambridge for the past two years, will also be attached to the centre. Inquiries on the documentation centre should be addressed to the Librarian, Miss Julia Allen, Afro-Asian Group, Faculty of Economics, Sidgwick Avenue, Cambridge. Inquiries on the programme of the group should be made to Mr. Kenneth Berrill at the same address.

\section{Sorbonne - Ecole Pratique des Hautes Etudes (VIe Section): Initiation à la recherche africaniste}

UN enseignement d'initiation à la recherche africaniste fonctionnera au cours de l'année universitaire 1961-2 à l'École Pratique des Hautes Études, section des sciences économiques et sociales. Il est principalement destiné aux étudiants inscrits en première année du $3^{\circ}$ Cycle de l'Enseignement Supérieur et dont les travaux exigeront une connaissance d'ensemble des problèmes spécifiques de la recherche en Afrique Noire.

Cet enseignement est ouvert aux étudiants de toutes disciplines, quelle que soit la Faculté ou l'Institution d'Enseignement Supérieur dans laquelle ils auront pris leur inscription. Il est obligatoire pour les étudiants qui prendront cette inscription à l'École Pratique des Hautes Études, section des sciences économiques et sociales (Centre d’Études Africaines).

Le programme d'étude s'étendra du I er décembre I96I au I ${ }^{\text {er }}$ juin I962. Il comprendra des cours de préparation à la recherche, des travaux pratiques, des séminaires consacrés à des études de cas, organisés dans chacune des disciplines africanistes suivantes: géographie humaine, histoire, linguistique afticaine, ethnologie générale, ethnologie politique, ethnologie économique.

Ce cycle entre dans sa deuxième année. En I960-I il a groupé une trentaine d'étudiants dont deux-tiers environ de Français.

\section{A Russian Ethnographic Map of Africa}

An ethnographic map, Karta Narodov Afriki (Map of the Peoples of Africa), has recently been published by the Institut Etnografii in Moscow. The map is in two sheets, divided along the equator, and on a scale of $\mathrm{I}: 8,000,000$. Ethnic groups are distinguished by colours, and eight population densities by shading. Areas of mixed population are indicated in four differing ratios. Numerals locate particular peoples given in the key, as only major ethnic groups are named on the map. Rivers and towns are shown but not contours. Political and administrative boundaries are as at the end of 1960. 